Pobrane z czasopisma Annales $\mathrm{H}$ - Oeconomia http://oeconomia.annales.umcs.pl Data: 26/04/2023 10:47:28

DOI:10.17951/h.2017.51.2.9

\begin{tabular}{lcc}
\hline \multicolumn{3}{c}{ A N N A L E S } \\
UNIVERSITATIS MARIAE CURIE-SKŁODOWSKA \\
LUBLIN - POLONIA \\
VOL. LI, 2 & SECTIOH H \\
\hline
\end{tabular}

University of Life Sciences in Lublin, Department of Management and Marketing

\author{
MAREK ANGOWSKI \\ marek.angowski@up.lublin.pl \\ KATARZYNA DOMAŃSKA \\ katarzyna.domanska@up.lublin.pl \\ AGNIESZKA KOMOR \\ agnieszka.komor@up.lublin.pl
}

\title{
The Impact of Promotional Measures on the Buying Behaviour of Young Consumers on the Food Market
}

Wpływ działań promocyjnych na zachowania zakupowe młodych konsumentów na rynku żywności

Key words: promotion tools; food market; consumer behaviour; young consumer

Słowa kluczowe: narzędzia promocji; rynek żywności; zachowania konsumentów; młody konsument

JEL codes: D12; M30

\section{Introduction}

Knowing the preferences and behaviour of customers is the key factor determining the market success of enterprises. Customers' behaviour on the market is the result of many economic and non-economic determinants, which stem from environmental conditions and are connected with the internal conditions of the consumer as an individual. Marketing factors are among the major factors determining buying decisions [Angowski and Domańska 2015, pp. 385-389; Bondos 2014, pp. 20-27; Mirońska 2010, pp. 114-132; Szwacka 2007, pp. 81-95]. 
One of such marketing factors, which in addition to being most visible has a powerful influence on the buying decisions made by customers, is promotion. In order for decisions in the field of designing the promotional mix to be effective, they should be based on up-to-date and reliable information about consumers - their decisions, behaviour and attitudes [Michalak and Merło 2015, pp. 141-151]. The individual promotional instruments have various functions and can support the implementation of various market objectives.

Getting to know consumer behaviours and factors influencing them constitutes a basis for effective segmentation, and modern marketing requires segmentation which is precise. It makes it possible to create personalised marketing strategies, aimed at specific customers and taking into account the needs and interests of the target group [Mącik and Mącik 2015, pp. 138-152; Lipowski and Angowski 2013].

\section{The aim of this paper and the methodology of author's research}

The main aim of this paper was to assess the impact of promotional measures on the buying process of young consumers on the selected food products markets. The publication attempts to answer the following questions:

- What promotional measures influence the decisions made by young respondents in respect of the purchase of food products?

- Is the gender of the respondents a variable that differentiates the impact of promotional measures on the buying behaviour of young consumers?

- Is the income of the respondents a variable that differentiates the impact of promotional measures on the buying behaviour of young consumers?

The empirical part was prepared based on surveys, which were conducted in 2016 and involved a group of 486 students, using the purposive sampling method. The main method of data collection was CAWI supported by PAPI. A questionnaire was prepared in the electronic form and connected to a database on the SurveyMonkey platform. The questionnaire consisted of 18 problem-related questions concerning the evaluation of the behaviour and attitudes of consumers on the food market, including the factors shaping the product selection process, with a particular focus on promotional measures, the extent, manner and place of shopping, and also questions characterising the respondent. 


\section{Promotional measures vs. the buying behaviour of young consumers on the food market - the results}

\subsection{The significance of the selected promotional measures on the food market}

In the first stage of the survey, the significance of the selected promotional measures in respect of decisions about food purchases made by young consumers was identified. The evaluation of the significance of individual promotional measures in the decision-making process about food purchases can be an important hint for salespeople as regards the way of creatively shaping the attitudes and the resulting behaviour on the food market. Sellers who wish to efficiently and effectively send their promotional messages to the purchasers should be aware of the types of measures which play a particularly significant role for the consumers.

The conducted surveys showed that price discounts were the most important promotional measures in respect of the analysed group of products (meat and dairy products, grain products, fruit and vegetables) (Figure 1). Special offers at the place of sale (e.g. two for one, a bigger packaging at a standard price, an extra item added to the product, etc.) and recommendations made by family and friends were also important. According to the young respondents, positive opinions about the product or producer in the mass media, seller's recommendations and product display at the place of sale, were also rather important.

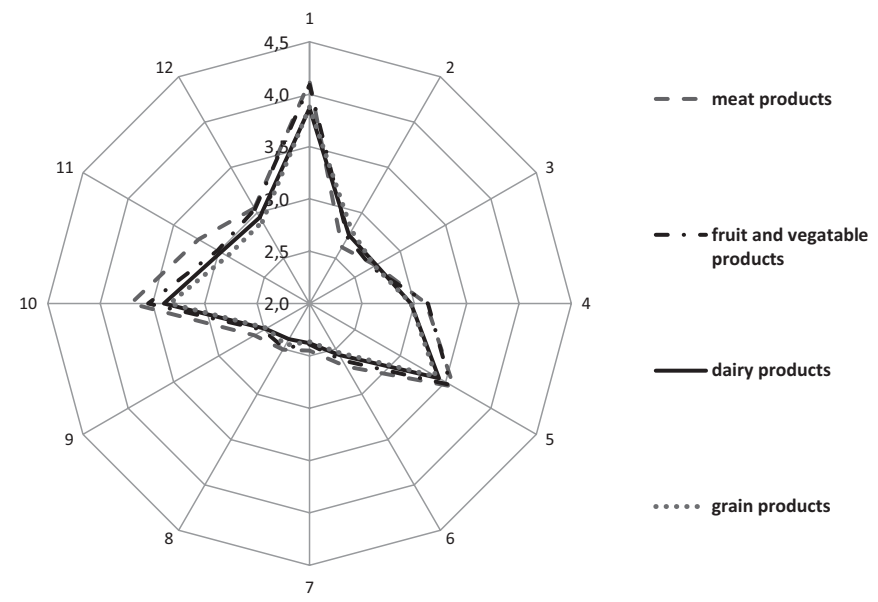

Figure 1. The evaluation of the significance of the selected promotional measures for the decisions about the purchase of food products

1 - Price discounts, 2 - Product tasting at the place of sale, 3 - Loyalty programmes, 4 - Product display at the place of sale, 5 - Special offers at the place of sale (e.g. two for one, a bigger packaging at a standard price, an extra item added to the product, etc.), 6 - TV commercials, 7 - Radio advertisements, 8 -Advertisements in the press, 9 - Advertising hoardings, 10 - Recommendations by family/friends, 11 - Positive opinions about the product/producer in the mass media, 12 - Seller's recommendations

Source: Authors' own work based on surveys. 
One can observe that in their buying process, the respondents pay the biggest attention to promotional measures of a financial nature (price discounts, special offers), positive stimuli influencing the image of the product, and product display at the place of sale. When it comes to these promotional measures, the most significant differences in the impact on the buying decision process can be observed. This is confirmed by a single-factor ANOVA analysis, indicating statistically significant differences between the evaluations of individual product groups. As found in surveys by Barska, economic stimuli encouraging consumers to buy a given product were ranked second in terms of the effectiveness of their impact on young consumers, with good location at the place of sale being the most important [Barska 2015, pp. 33-44].

It is worth highlighting that among the studied product groups, the respondents indicated the relatively strongest impact of promotional measures on buying decisions concerning meat products. The greater role of promotional measures of a financial nature, as compared to other measures, might result from relatively high prices of meat and meat preparations, when compared to other food products, and the commonness of its consumption. The significance of factors connected with the positive image of the product/producer might be connected with the issue of consumer confidence in products in the context of food safety. Consumer confidence in meat products was severely shaken by events connected with animal diseases (e.g. Creutzfeldt-Jakob disease in cattle, bird flu) and the irregularities in meat processing plants hitting the headlines (e.g. the sale of bad products by the Constar meat plant in Starachowice) [Jakubowska and Radzymińska 2009, p. 245].

Other measures used in the promotion include tasting at the place of sale. According to the young respondents, these measures contribute relatively the most to their decisions to buy grain products. Another group of promotional measures involves loyalty programmes. As regards the importance of loyalty programmes as promotional measures, no significant differences were observed in respect of the studied product groups. According to the respondents, the various forms of advertising (commercials, hoardings, advertising in the press and on the radio) were the least important as regards their impact on their buying behaviour.

\subsection{Promotional measures vs. the gender of the young respondents}

The next stage of the survey analysed the interconnections between the impact of promotional measures on buying decisions made in respect of the selected food product groups, and the gender of the young respondents. Getting to know the importance of promotional measures depending on the gender has important practical implications, as the sellers can use such information to better adjust their marketing measures to the specific profile of consumers.

As regards meat products, one should state that, when it came to making decisions about the purchase of such products, men attached greater importance to many of the analysed promotional measures than women (Figure 2). 

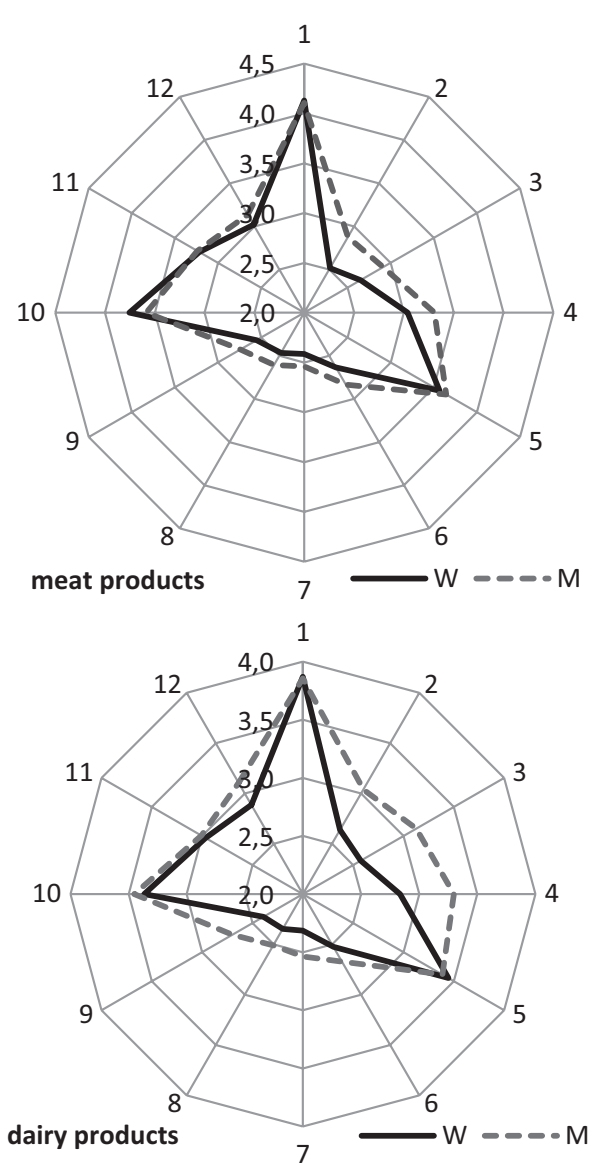
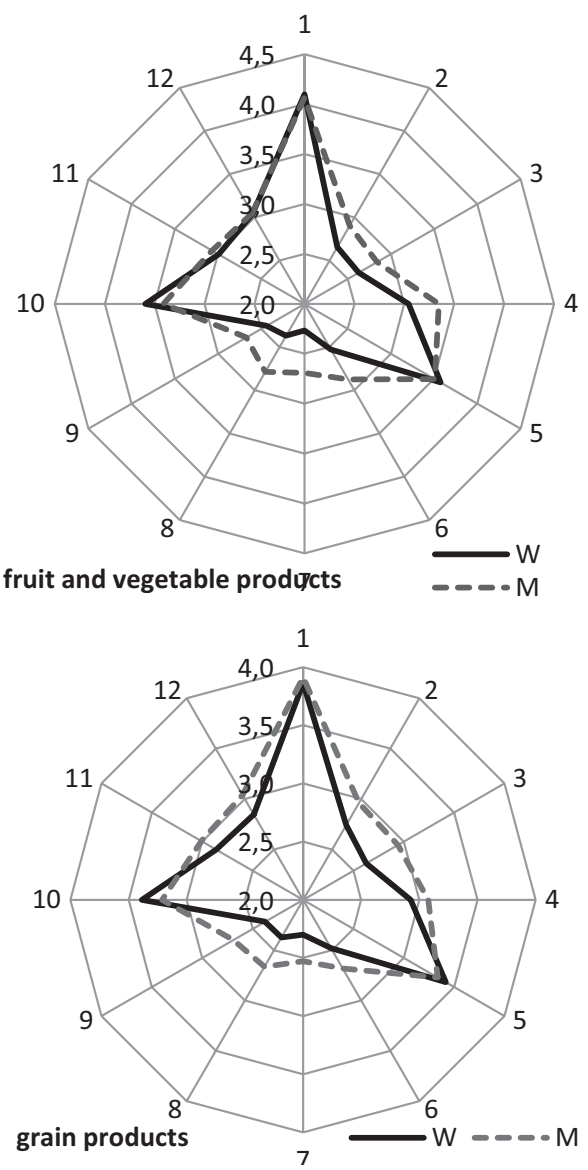

Figure 2. The evaluation of the significance of the selected promotional measures for the decisions about the purchase of food products (by respondent gender: $\mathrm{W}$ - women, $\mathrm{M}$ - men)

1 - Price discounts, 2 - Product tasting at the place of sale, 3 - Loyalty programmes, 4 - Product display at the place of sale, 5 - Special offers at the place of sale (e.g. two for one, a bigger packaging at a standard price, an extra item added to the product, etc.), 6 - TV commercials, 7 - Radio advertisements, 8 -Advertisements in the press, 9 - Advertising hoardings, 10 - Recommendations by family/friends, 11 - Positive opinions about the product/producer in the mass media, 12 - Seller's recommendations

Source: Authors' own work based on surveys.

This difference can be indicated, among other things, in relation to tastings at the place of sale, appropriate product display at the place of sale and the use of loyalty programmes. It is worth noting, however, that the difference was not particularly significant. Price discounts, special offers at the place of sale, and positive opinions about the product/producer in the mass media were of similar importance for the surveyed men and women. The surveyed women attached relatively greater importance than men to measures connected with the so-called word-of-mouth marketing, 
which involved taking into account recommendations made by family and friends in the buying decision process.

Over the course of the surveys, it was demonstrated that the significance of the impact of individual promotional measures on the purchase of fruit and vegetables by surveyed men and women was similar as in the case of meat products. One exception was seller's recommendations, which have similar significance, for men and women alike, in terms of their impact on the decision-making process involving fruit and vegetables (when it came to meat products, men tended to attach somewhat greater importance to such promotional measures than women). It is worth noting the promotional measures which were found to exhibit more differentiation in terms of their impact in relation to gender - these were all kinds of advertisements of fruit and vegetables (commercials, and advertisements in the press and on the radio), their display at the place of sale, and tastings at the place of sale. The aforementioned promotional measures were more important for the surveyed women than men.

An analysis of promotional measures connected with grain products, in relation to the gender of the young respondents, indicated that most such measures are more important for the surveyed men than women (although the difference was not significant). Differences in this regard were observed in respect of the use of loyalty programmes, various forms of advertising (commercials, hoardings, advertisements in the press and on the radio), and holding tastings at the place of sale. Women attached relatively greater importance than men to recommendations made by family and friends. The impact of measures involving discounts on grain products and the use of special offers at the place of sale to shape the desired buying behaviour in the respondents was not gender-dependant.

The impact of most promotional measures on the buying behaviour in respect of dairy products was more important for the surveyed young men and women. This was especially the case for loyalty programmes, appropriate display of dairy products at the place of sale and the holding of tastings. Over the course of the surveys, no differences were found in the perceived significance of promotional measures in relation to the gender of the respondents for the following measures: price discounts, special offers at the place of sale, positive opinions about the product/producer in the mass media, and recommendations by family and friends. 


\subsection{Promotional measures vs. the income of the young respondents}
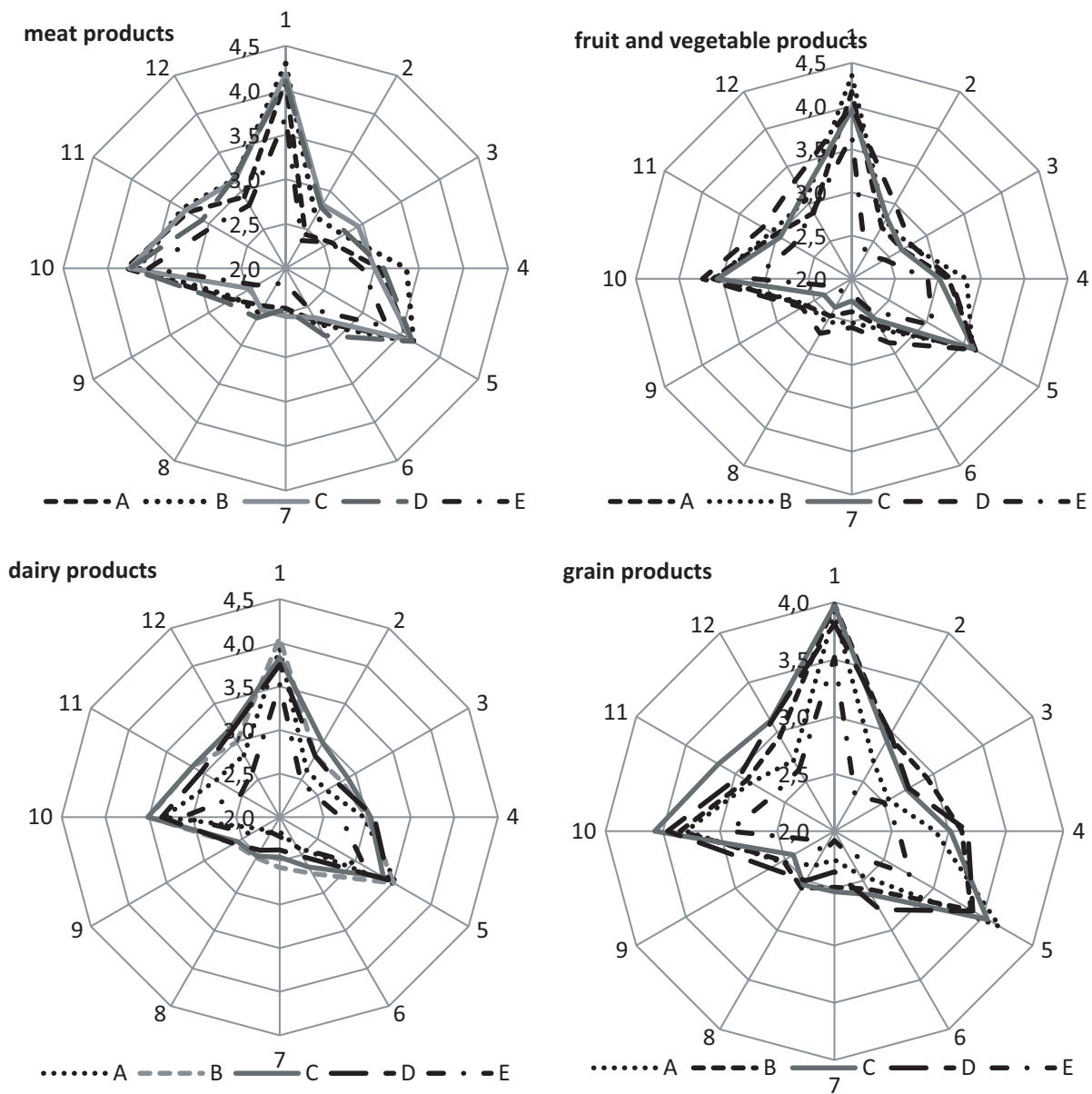

Figure 3. The evaluation of the significance of the selected promotional measures for the decisions about the purchase of food products (by respondent income: A - up to PLN 750, B - PLN 751-1,000, C - PLN 1,001-1,250, D - PLN 1,251-1,500, E - over PLN 1,500)

1 - Price discounts, 2 - Product tasting at the place of sale, 3 - Loyalty programmes, 4 - Product display at the place of sale, 5 - Special offers at the place of sale (e.g. two for one, a bigger packaging at a standard price, an extra item added to the product, etc.), 6 - TV commercials, 7 - Radio advertisements, 8 -Advertisements in the press, 9 - Advertising hoardings, 10 - Recommendations by family/friends, 11 - Positive opinions about the product/producer in the mass media, 12 - Seller's recommendations

Source: Authors' own work based on surveys.

When analysing the significance of individual promotional measures, with income in mind, one can observe the following trends evident in both groups of respondents:

- As the income increases, the significance of special offers decreases in the decision-making process of young consumers. 
- The greatest differences in responses in the individual income groups can be observed between the consumers with the highest income and the rest. This is corroborated by the single-factor ANOVA analysis, indicating statistically significant differences between the evaluations in these groups, as regards price discounts, special offers and product display at the place of sale. Smaller differences can be also seen in the case of advertisements in the press and on the radio.

- The most internally disparate responses by income were found in the group of meat buyers, and the most uniform in the group of dairy product buyers.

- When analysing the ranking of the significance of individual promotional measures for the decision-making process, one can note similarities in every income group. Price discounts, special offers and recommendations are the most important, while advertisements on the radio, in the press and on hoardings are the least significant.

\section{Conclusions}

1. As a result of the conducted surveys and analyses, it was found that the individual types of promotional measures had a different impact on food buyers in terms of their buying decisions. The differences, however, were not significant. The most important role, in relation to all the studied product groups, was played by price discounts, followed by special offers at the place of sale and recommendations by family and friends.

2. The perception of the roles of individual promotional measures in the decision-making processes of the surveyed respondents was different depending on their gender; however, as shown by statistical analyses, the differences were insignificant. The surveyed men attached greater importance to the use of loyalty programmes, the holding of tastings at the place of sale, appropriate product display, and the use of various forms of advertising. The surveyed women, on the other hand, attached relatively greater importance to recommendations made by family and friends.

3. Also when comparing income groups, one can note slight differences in the significance of individual promotional measures for the choices of the surveyed consumers. Promotional measures have the greatest impact on the buying decisions of consumers with the smallest incomes: up to PLN 750 and PLN 751-1,000 and are much less important for those with the highest incomes.

4. Over the course of survey, promotional measures were identified whose impact on the buying behaviour of the respondents was not conditional on the gender or income of respondents. These included first and foremost price discounts and special offers at the place of sale. 
5. The slight differences in the significance of individual promotional tools, as observed between men and women, and people from different income groups can be the result of globalisation, which is associated with market homogenisation and the popularisation of a universal model of consumption. It is an important trend characteristic of the food market.

\section{Bibliography}

Angowski, M., Domańska, K., Czynniki wptywające na wybór miejsca dokonywania zakupu na rynku serów żóltych na przyktadzie serów dtugodojrzewających, "Zeszyty Naukowe Uniwersytetu Szczecińskiego. Problemy Zarządzania, Finansów i Marketingu”, no. 41, 2015, pp. 385-397.

Barska, A., Komunikacja marketingowa z młodymi konsumentami na rynku żywności, "Handel Wewnętrzny", no. 2(355), 2015, pp. 33-44.

Bondos, I., Price Sensitivity of Polish Buyers of Durable Goods, “Логистика. Львовская Политехника”, no. 811, 2014, pp. 20-27.

Jakubowska, D., Radzymińska, M., Postawy i zachowania nabywcze konsumentów wybranych narodowości wobec ryzyka zwiąanego z konsumpcja produktów mięsnych, "Zeszyty Naukowe Ostrołęckiego Towarzystwa Naukowego", no. 23, 2009, pp. 245-252.

Mącik, R., Mącik, D., Style podejmowania decyzji zakupowych konsumenta oraz ich pomiar, "Studia Ekonomiczne. Zeszyty Naukowe Uniwersytetu Ekonomicznego w Katowicach”, no. 236, 2015, pp. 138-152.

Michalak, J., Merło, P., Wpływ działań promocyjnych na zachowania nabywców samochodów, "Handel Wewnętrzny", no. 3(356), 2015, pp. 141-151.

Mirońska, D., Zachowania nabywców na rynku - trendy $i$ wptyw na działanie przedsiębiorstw, "Zeszyty Naukowe Szkoły Głównej Handlowej, Kolegium Gospodarki Światowej”, no. 27, 2010, pp. 114-132.

Lipowski, M., Angowski, M., Competitiveness of Small Grocery Stores in Poland During the Economic Slowdown, “Логистика. Львовская Политехника”, по. 762, 2013, pp. 96-104.

Szwacka, J., Kierunki zmian na rynku żywnościowym w Polsce, "Zeszyty Naukowe SGGW. Ekonomika i Organizacja Gospodarki Żywnościowej”, no. 62, 2007, pp. 81-95.

\section{The Impact of Promotional Measures on the Buying Behaviour of Young Consumers on the Food Market}

The main objective of this paper was to assess the impact of promotional measures on the buying process of young consumers on selected food products markets. The empirical part was prepared based on surveys, which were conducted in 2016 and involved a group of 486 students using the purposive sampling method. As a result of the conducted surveys, it was determined that the individual types of promotional measures had a different impact on food buyers in terms of their food-buying decisions. The differences, however, were not significant. The most important role, in relation to all the studied product groups, was played by price discounts, followed by special offers at the place of sale and recommendations by family and friends. 
Pobrane z czasopisma Annales H - Oeconomia http://oeconomia.annales.umcs.pl Data: 26/04/2023 10:47:28

\section{Wpływ działań promocyjnych na zachowania zakupowe młodych konsumentów na rynku żywności}

Celem głównym pracy była ocena wpływu działań promocyjnych na kształtowanie się procesu zakupowego młodych konsumentów na rynku wybranych produktów żywnościowych. Część empiryczną opracowano na podstawie badań sondażowych, które zostały przeprowadzone w 2016 roku na grupie 486 studentów przy wykorzystaniu metody doboru celowego. W wyniku przeprowadzonych badań wykazano, że poszczególne rodzaje działań promocyjnych miały dla badanych młodych nabywców żywności zróżnicowane znaczenie w procesie podejmowania decyzji o zakupie żywności, choć różnice te nie były duże. Najistotniejszą rolę w odniesieniu do wszystkich badanych grup produktów miały rabaty cenowe, a w dalszej kolejności promocje handlowe w miejscu sprzedaży, a także rekomendacje rodziny i znajomych. 